IRSH 52 (2007), pp. I 53-I68 DOI: I0.1017/S0020859007003I73

(C) 2007 Internationaal Instituut voor Sociale Geschiedenis

\title{
“A Laughter That Will Bury You All”: Irony as Protest and Language as Struggle in the Italian I977 Movement*
}

\author{
PATRICK Gun Cuninghame
}

Summary: Perhaps the most innovative aspect of the Italian “I 977 Movement” in its conflict with the grey, humourless political system was its use of irony to ridicule its opponents. Irony was central to the identity of the movement and its cultural and political break with the institutional old and vanguardist new lefts. Its use, particularly by the "Metropolitan Indians", the transversalists and other "creatives", marked a social revolt by mainly marginalized young people, who invented a new political counter-culture based on linguistic experimentation in circumstances far from the optimism of 1968 . The paper, based directly on primary sources from the movement and on interviews with former participants, reassesses a movement usually characterized as "violent" by Italianist social history. It concludes that the movement's "ironic praxis" contributed to a fundamental change in Italian society in the late seventies and has influenced the political style of contemporary alterglobalist and anti-capitalist movements.

"The revolution is over. We have won."

$(Z u t / A / \text { traverso, Bologna, June I977) })^{\mathrm{I}}$

\footnotetext{
* This article is based on a paper, “The End of Politics: The 1977 Movement in Italy", presented at the annual conference of the Association for the Study of Modern Italy, London, in November 1997; and also on ch. 6, "Youth Counter-Cultures and Antagonist Communication: 'Creative Autonomia' and the 1977 Movement", of my unpublished Ph.D. thesis, Autonomia: Movement of Refusal: Social Movements and Conflict in Italy in the I970s (Middlesex University, 2002). I am indebted to Enrico Palandri and Ferruccio Gambino for sharing their experiences with me and for providing valuable insights through in-depth interviews. I thank Franco Berardi, Bob Lumley, Nick Dyer-Witheford, and Autonomedia for providing permission to quote. I also thank Laura Corradi, Gavin Grindon, Alejandro Suero and Steve Wright for their comments, corrections and additional sources. Finally, all translations of quotations from Italian and Spanish texts are mine, as are any errors. The first part of the title is taken from the title of collected ephemera of Proletarian Youth Circles movement and is a wordplay on an old anarchist slogan, converted into "It will be a risotto that will bury you all", Circoli proletari giovanili di Milano (eds), Sarà un risotto che vi seppellirà (Milan, 1977).

I. "La rivoluzione è finita, abbiamo vinto", ironic headline in one of the main newspapers of the "creative" wing of the Seventy-Seven Movement; quoted in Francesco Berardi, Dell'Innocenza. 1977: l'anno della premonizione (Verona, I997), p. 50.
} 


\section{INTRODUCTION}

The 1977 Movement (known as settantasette - "Seventy-Seven" - in Italy) marked the end of Italy's "long sixty-eight", which had lasted for a decade, as compared to a few weeks in France and elsewhere. While the iconoclastic punk movement screamed "No future" in Britain, perhaps the main weapon of the revolt of "Year Nine" ${ }^{2}$ against the austere, humourless, bureaucratic authoritarianism of the Italian Communist Party (ICP), and its "Historical Compromise" 3 with the corrupt Christian Democrat regime, was its caustic irony and satirical wit. This was particularly the case with the "Metropolitan Indians" (indiani metropolitani): largely non-violent demonstrators who used face paint and headdresses to signify their break from the "seriousness" of politics and emphasize the theatrical and ludic aspects of protest.

This article aims to outline the rationale behind the "creative" wing of Seventy-Seven and its "scream" against official politics of whatever hue and anything within the Left, both Old and New, that smacked of dullness, self-importance, dogmatism and hypocrisy. It will show how humour in its historically most political form, irony, was central to the identity of the movement and its fundamental cultural, as much as political, break with both the institutional Old Left (ICP and Socialist Party) and the vanguardist New Left of 1968 origin.

This was the linguistic, artistic, cultural and, ultimately, despite its "antipolitical" ethos, political revolution of the "Second Society":4 students, unemployed youth, precarious workers, and other "marginals" excluded from the twilight of the Keynesian-Fordist pact and forced to reinvent a new political praxis in very different circumstances from the optimism of 1968. Often wittily ironic, sometimes aggressively sarcastic, always disparaging, Seventy-Seven's use of creative humour also had devastating political consequences. Such was the case of the expulsion of Luciano Lama, an ICP leader and head of the CGIL's trade unions, who along with his bodyguards and several hundred press-ganged trade unionists, was

2. In Sette anni di desiderio: cronache $1977-1983$ (Milan, 1985 [1983]), Umberto Eco gives this name to the 1977 Movement. "Year One" was 1968, the historical break between the Old and New Lefts.

3. Following the I973 coup d'état in Chile, the ICP's leadership concluded that the parliamentary road to socialism was closed. Enrico Berlinguer, the ICP's party secretary, devised the Historic Compromise strategy to increase electoral support among the middle classes. The severe crisis of the seventies caused the Christian Democrats and ICP to agree on the need to restabilize the Italian state and organize social consensus for economic austerity measures.

4. A theory outlined by Alberto Asor Rosa in Le due societá (Turin, 1977). See section on "Two Societies" for further analysis.

5. Confederazione Generale Italiana del Lavoro (Italian General Confederation of Labour), the largest of the three union confederations and close to the ICP and the Italian Socialist Party. 
unceremoniously driven out of Rome University, after attempting forcibly to end an occupation: an historical turning point that marked the definitive end of the ICP and the New Left's mutual tolerance and the rupture of any possible "Left unity" in that country. ${ }^{6}$

This article will examine the how and why behind an extraordinary panoply of slogans, graffiti, chants, zines, happenings, street theatre, and free radio stations. Bologna's "creative Autonomia" [Autonomy] also produced "Mao-Dadism", the melding of the Maoism of the Cultural Revolution with the Dadaism of interwar artistic nihilism. Another current was "transversalism": the attempt by the A/Traverso magazine collective to deconstruct autonomia, ${ }^{7}$ operaismo (workerism), ${ }^{8}$ and the Left in general. While Mao-Dadaism and transversalism took themselves more seriously, they shared with the Metropolitan Indians' ironic slogans the same subversive intent to "turn the world upside down" by playfully undermining the linguistic and cultural norms of both capitalism and socialism. The article concludes by tracing links between Seventy-Seven's celebration of humour as political event and the sometimes theatrical praxis of contemporary alter-globalist and anti-capitalist movements.

\section{“A STRANGE MOVEMENT OF STRANGE STUDENTS”}

The mass movement that emerged in Rome and Bologna, in particular, in February-April I977 was categorized by the ICP intellectual and moderate workerist, Asor Rosa, as the "Second Society": a nomadic amalgam of university and secondary school students, unemployed and counter-cultural youth, feminists, homosexuals, artists, and unaffiliated ex-New Left activists known as cani sciolti (stray dogs), plus autonomia (Figure I overleaf) and the remnants of the New Left parties. ${ }^{10}$ The counter-cultural and anti-political components that had been prominent in the 1968 movements returned to the fore to challenge the neo-Leninist and

6. I thank Alejandro Suero for sharing with me his idea that such events are more important in "epoch-making" than repression, the latter usually taken as marking the end of a cycle of social movement mobilization and therefore of a specific epoch.

7. A social movement produced by the disintegration of the New Left groups in the mid-I970s and a general disaffection among young activists with the party form. See Steve Wright, Storming Heaven: Class Composition and Struggle in Italian Autonomist Marxism (London, 2002) and my unpublished Ph.D. thesis.

8. Italian operaismo was born in the late I950s and emphasized workers' autonomous selforganization, while criticizing trade-union-based "workerism". For a definitive history of operaismo, see Wright, Storming Heaven.

9. L. Manconi and M. Sinibaldi, "Uno strano movimento di strani studenti", Ombre Rosse, 20 (1977), pp. $28-$ n/a.

Io. Lotta Continua [Continuous Struggle], Avanguardia Operaia [Workers' Vanguard], Il Manifesto (now a national daily newspaper), Potere Operaio [Workers' Power] plus a galaxy of smaller groups. 


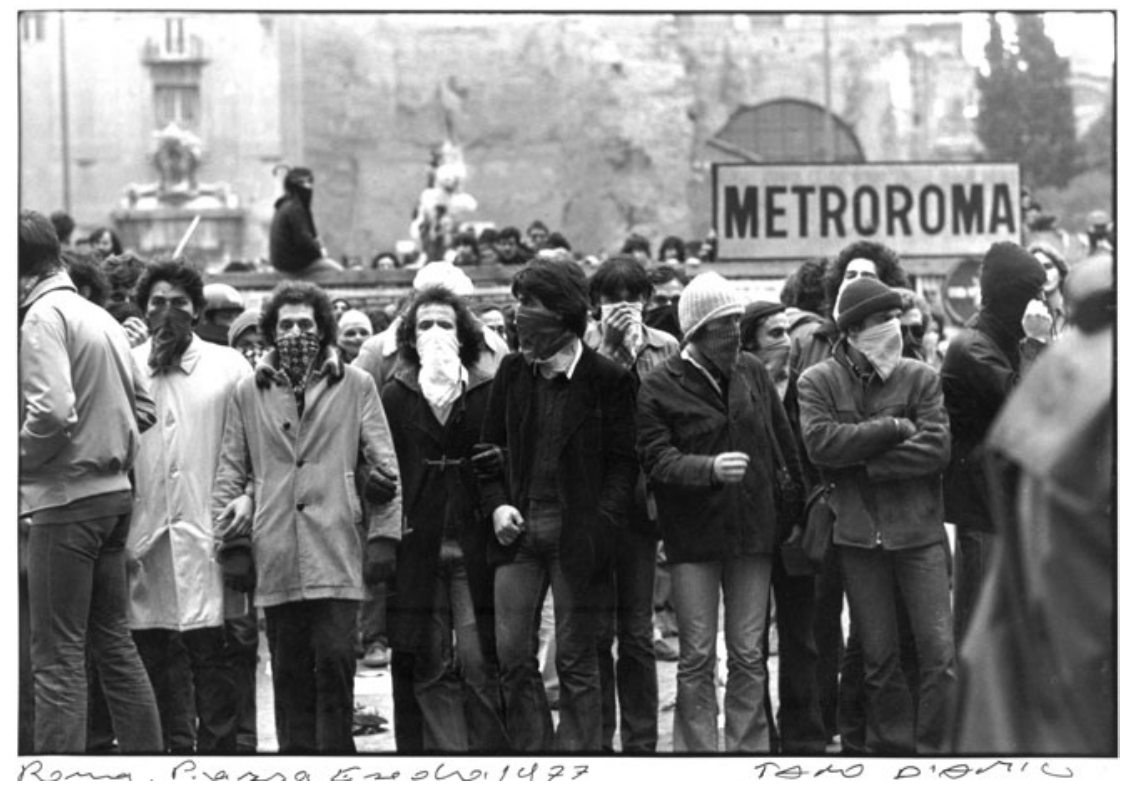

Figure I. The seriousness of the "autonomi" contrasted with the playfulness of the Metropolitan Indians and other counter-cultural elements in the movement.

Copyright: Tano D'Amico. Used with permission.

workerist premises of organized Autonomia through the ironic communicative action of the Metropolitan Indians and the linguistic transversalism of "creative autonomia".

However, unlike 1968, there was no workers' movement in tandem or potential allies in the institutional Left. Its "Historic Compromise" with the Christian Democrats had led the ICP from a position of relative neutrality in 1968 to open hostility towards the more radical 1977 Movement. The movement perceived the ICP's leaders as even more rigid than the political Right in their insistence on austerity and repressive measures to pacify the severe crisis of the mid-I970s, including the highly unpopular plans to restructure the universities which sparked off SeventySeven. Despite its social-democratic shift towards Eurocommunism, the ICP retained its "Stalinist soul", took a conservative stance on the divorce and abortion referendums and seemed unable to appreciate the significance of the new social movements. ${ }^{\text {I }}$ The rupture with the party system was complete and only one side could emerge intact from such an uncompro-

I I. Antonio Negri, "Between 'Historic Compromise' and Terrorism: Reviewing the Experience of Italy in the 1970s", Le Monde Diplomatique (English edn, trans. Ed Emery), September (1998); http://www.monde-diplomatique.fr/en/r 998/og/r r negri (accessed April 200r). 
mising confrontation, as Ferruccio Gambino, a sociologist and former Potere Operaio (Workers' Power) ${ }^{\mathrm{I} 2}$ militant, states:

Basically they were strangers in their own land. When they turned their heads it was not like in Corso Traiano [major riot in a working-class district of Turin] in I969, when there were 5,000 workers behind the students. This time there were no workers. That makes a difference and I think they paid very dearly for that. It was a much more difficult situation than in $1969 .{ }^{13}$

Whereas I968 saw an explosion of antagonist movements, behaviours, and mentalities that spread throughout Italian, and indeed global society, synchronizing with a profound process of social, economic, and cultural crisis and change, 1977, as the culmination of that process, represented its implosion and dispersion throughout society in an individualized rather than collective form. The outburst of political, social, and cultural innovation and creativity represented by Seventy-Seven ultimately fell into a void of repression and terrorism, its actors unable to maintain the tremendous momentum of February and March. Autonomia, as a postNew Left mass entity, was the only overtly political movement in SeventySeven. However, organized autonomia's attempts to hegemonize the movement and to "raise the level of conflict" with the state caused a permanent internal dispute, whose divisive effects contributed to the movement's crisis and premature demise. Revisionist post-Marxist sociological accounts have emphasized Seventy-Seven's violent, self-destructive tendencies, while minimizing its creative, humorous characteristics. ${ }^{14}$ Sympathetic radical, Marxist, and autonomist accounts have stressed its innovatory contribution to the evolution of contemporary Italian, European, and now global social movements, given the strong Italian influence within alter-globalism. ${ }^{\text {Is }}$

\section{RUPTURE WITH THE ICP}

However, the most important difference between the movements of 1968 and 1977 was without doubt the very different relations between the social

I 2. An operaismo-influenced group which pushed for the alliance between the libertarian I 968 students' movement and the autonomous workers movement of the I 969 "Hot Autumn" strikewave. Many of its militants and intellectuals later became involved in autonomia and SeventySeven.

I3. Interview with Ferruccio Gambino, June 1999 (Padua).

14. Donatella Della Porta, Movimenti collettivi e sistema politico in Italia 1960-1995 (Rome, 1996); Robert Lumley, States of Emergency: Cultures of Revolt in Italy from 1968 to 1978 (London, I990); Alberto Melucci, Challenging Codes: Collective Action in the Information Age (Cambridge, 1996).

I s. Berardi, Dell'innocenza; Marco Grispigni, Il Settantasette: Un manuale per capire, un saggio per riflettere (Milan, 1997); George Katsiaficas, The Subversion of Politics: European Autonomous Social Movements and the Decolonization of Everyday Life (Atlantic Highlands, NJ, 1997). 


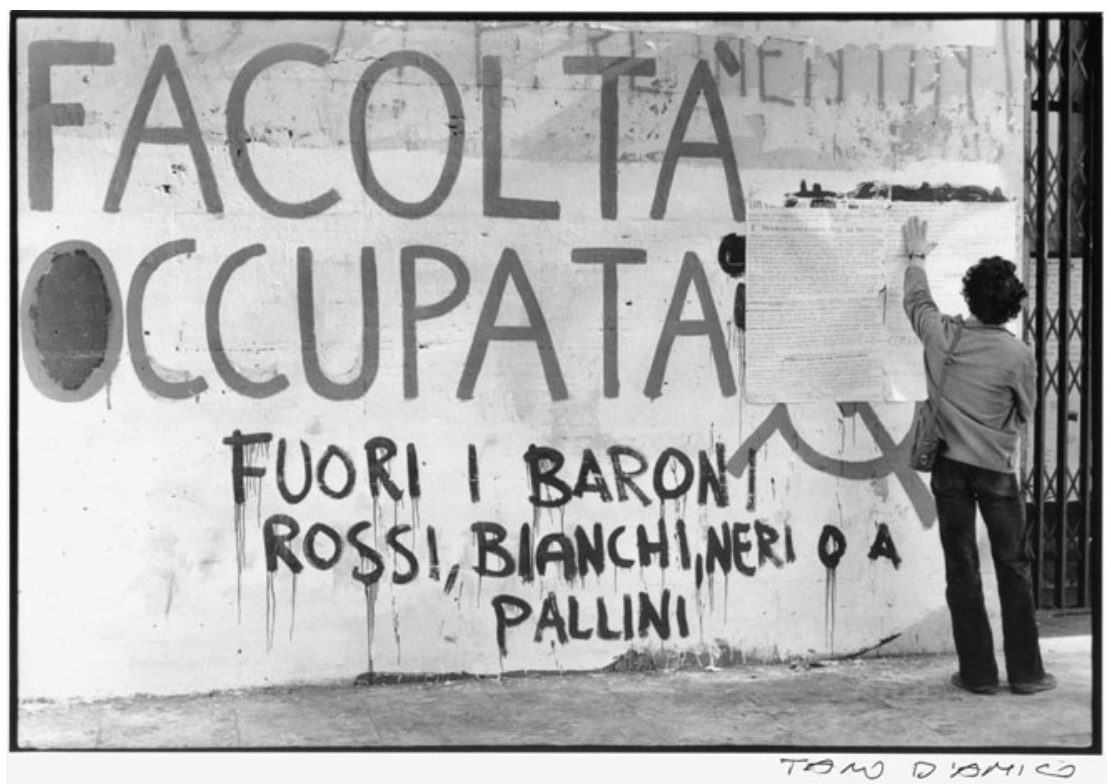

Figure 2. "Faculty occupied. Barons [senior academics linked to parties] out, red, white, black or with spots”, Rome University, February 1977.

Copyright: Tano D'Amico. Used with permission.

movements and their historical mediator with the state, the ICP, which had been the main beneficiary, in terms of votes, from the upsurge of the social movements after 1968, almost overtaking the Christian Democrats in the 1976 national elections. It was not hard to predict the conflict between Seventy-Seven and the ICP, but its ferocity, particularly the incident with Lama, the CGIL leader, at Rome University on i7 February took most by surprise.

The movement exploded exactly in those parts of the social terrain considered to be securely occupied by the ICP, namely the universities and "Red Bologna", the capital of Emilia-Romagna, the main region of the "Red Belt" of northern central Italy and the ICP's showpiece for its local government strategy of cooperation with the small- and medium-scale industry of the so-called "Third Italy". ${ }^{16}$ A generally contemptuous attitude led to the disastrous miscalculations that brought about Lama's misconceived attempt forcibly to "normalize" the university and end the occupation (Figure 2). His accompanying group of about 300 ICP and CGIL militants was too small and divided. Many factory workers left as 
soon as they realized they were not confronting "fascists" as they had previously been informed.

The Metropolitan Indians drowned out Lama's harangue with their mocking chants, provoking a violent reaction:

In the large open area of the campus where he was to speak, Lama found another platform already rigged up, with a dummy of himself on it (complete with his famous pipe). There was a big red cutout of a Valentine's heart, with a slogan punning his name - "Nessuno L'Ama" [Lama Nobody [...] or Nobody Loves Him]. Around this platform there was a band of Metropolitan Indians [Figure 3 overleaf]. As Lama started to speak, they began to chant "Sacrifices, Sacrifices, We Want Sacrifices!" (a parody of the State's economic policy upheld by the Communist Party). "Build us More Churches and Fewer Houses!” (Italy has more churches than any other European country, and a chronic housing shortage). "We demand to work harder and earn less!" [...]. The irony aggravated the humourless heavies. ${ }^{17}$

Then came the more violent anger of the autonomi who responded with a hail of stones to the aggression of Lama's minders who had attacked the Metropolitan Indians with fire extinguishers. Lama and his entourage were pushed out of the campus and the truck with his loudspeaker system was smashed up. Both sides taunted each other with shouts of "fascists", a deadly insult for an Italian leftist. Others broke down and wept, overwhelmed by the historic significance of the moment: the Rubicon had been crossed and the Italian Left was now irredeemably split. The damage done was irreversible and the split between the ICP and the movement had become an unbridgeable abyss, locking both into an increasingly bitter confrontation, particularly after Renato Zangheri, the ICP mayor of Bologna, defended the killing of a student activist by riot police on I I March.

\section{THE "TWO SOCIETIES"}

The shock of Lama's humiliating expulsion forced the ICP's intellectuals to analyse seriously a movement that until then they had only derided or ignored. The counter-attack was led by the ICP's Asor Rosa in a series of articles in $L^{\prime} U_{n i t a ́}{ }^{18}$ in which he outlined his theory of the "two societies": a "first society" composed of "guaranteed" social strata, attached to the unions and political parties, whose interests were considered to be synonymous with those of the Historic Compromise; and a "second society" composed of "non-guaranteed" marginalized social subjects, particularly the young unemployed and underemployed trapped in

17. Anon., "Lama Sabachthani”, in Italy: Autonomia. Post-Political Politics (New York, 1980), pp. IOO-IOI, IOI.

I8. The ICP's national daily newspaper. 


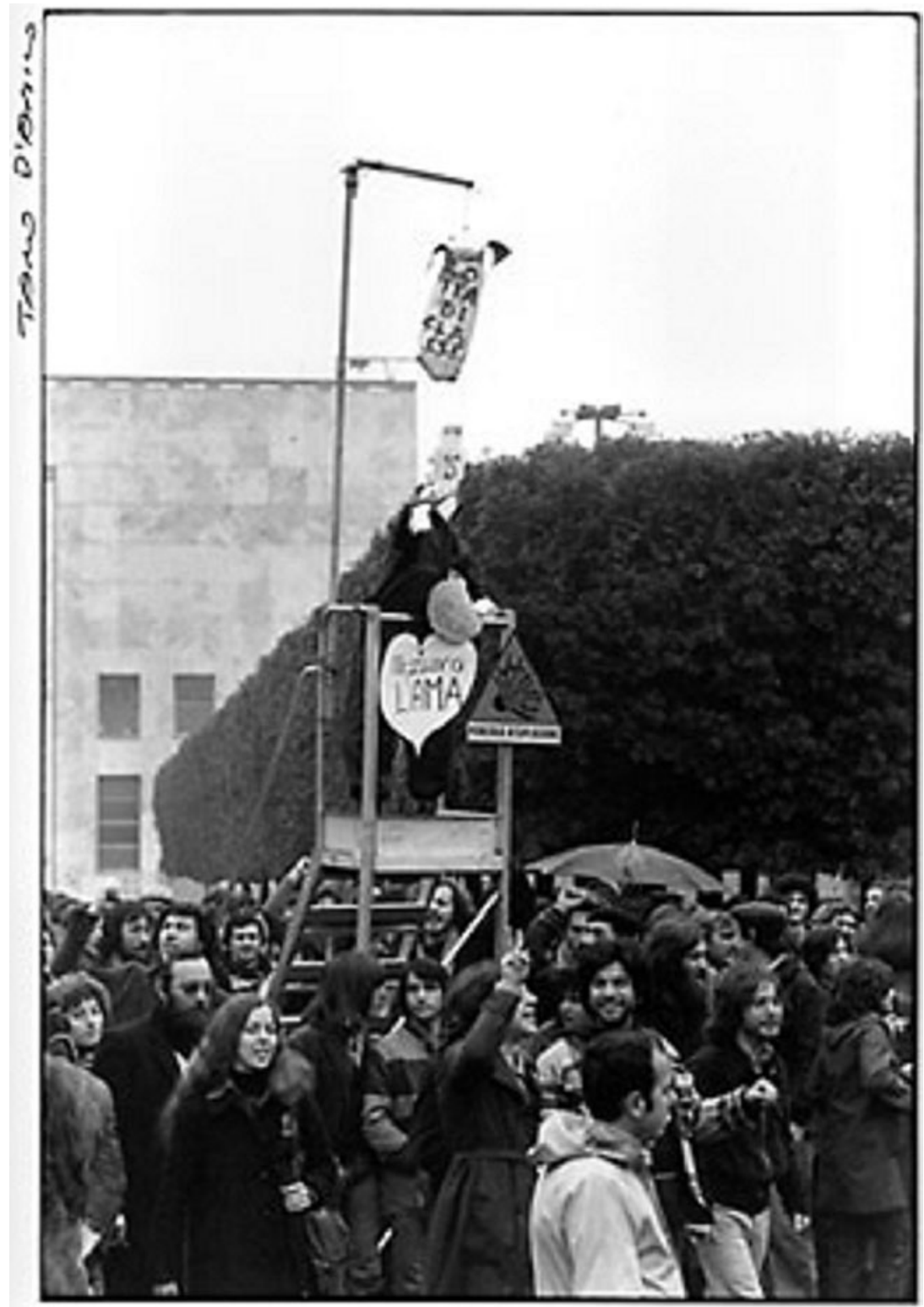

Figure 3. Metropolitan Indians and students prepare to greet Lama at Rome University, February 1977.

Copyright: Tano D'Amico. Used with permission.

unregulated black-market jobs, with whom an institutional dialogue over the "politics of austerity" implemented since 1973 to help the economy out of its worst postwar crisis was necessary if all but impossible. The interests 
of the "first society" were represented by the national party system and the unions, while the irreducibly marginalized "second society" self-organized locally in autonomous antagonist movements. This was also due to the failure of the historical workers' organizations to represent the nonguaranteed sectors, particularly youth, who were unprotected by labour laws and exploited in the growing sector of black market sweatshops.

Asor Rosa's theory was the first recognition of the movement's social complexity and cultural novelty. It recognized the limits of a social democratic strategy of "normalization", differing from the conspiracytheory-type analysis which typified the ICP's attempt to understand those movements, armed or otherwise, to its left. However, his theory remained flawed, contradictorily accusing the movement of being both "hedonistically apolitical" and "politically anti-communist". It expressed no appreciation of the movement's attack on politics itself, one of its most novel characteristics, nor of the impending crisis in the Fordist productive model, based on the "pact between producers". The "first society", in fact, was also destined for defeat and the erosion and removal of its guarantees in the aftermath of the collapse of the I980 FIAT strike. Asor Rosa attempted to make the new conflicts conform to an older model based on historical class divisions; a frequent mistake in Marxist analyses of new social movements.

\section{METROPOLITAN INDIANS}

Seventy-Seven surprised the New as much as the Old Left with its break with the generation and politics of I968, as the punks did with hippie values in Britain. They mocked the ageing "sixty-eighters" almost as harshly as the Old Left bureaucrats, calling them "zombies". The countercultural youth who had been on the fringes of the I $968-1973$ protest cycle became central to the new cycle of the mid to late nineteen seventies. However in Italy, as opposed to the UK punk scene, there was an unlikely mixing of Marx and the metropolitan underground:

They tended to coalesce [...] for some periods [but] they were also separated. I belonged to an area where they touched each other. I was neither a pure hippy nor a pure Marxist. We were in between. [...] On the other hand, there was Re $N u d o$ [underground magazine] and others who wouldn't want to hear about politics [...]. I wasn't ever in [RN], they were a bit too hippyish for my liking [...] for instance, I obviously did take drugs [...] but I never thought that would make an alternative world, whereas [RN] was very much into changing your diet [...]. It was almost a religious order $\left[\ldots . .{ }^{19}\right.$

19. Interview with Enrico Palandri, June 1999 (London). 
The self-description of "autonomy" was adopted as a blanket term to cover the "new politics", both "creative" and "organized". In Italy, youth subculture was linked to the political subculture of antonomia, "alternative" practices being politicized and made oppositional. Between 1975 and 1979 urban youth entered the political scene as the protagonist in new forms of urban conflict, its identity having been transformed by the student-worker politics of 1968-1973. This identity was not perceived exclusively in terms of youth experience, but more of the situation of the modern metropolis. Thus, youth became coterminous with exclusion, marginality, and deviance, and was treated by sociologists (except for Alberto Melucci) and institutions alike as a "social problem". This false image was appropriated and parodied by the Metropolitan Indians who mocked "Western civilization" and its values, seeing unemployment as an opportunity for self-development rather than a personal crisis or social problem. ${ }^{20}$

The Metropolitan Indians were the most visible counter-cultural force within Seventy-Seven. In Milan they emerged from a mixing of the experience of the Proletarian Youth Clubs (PYC) with "Mao-Dadaism", the "drug culture", group sex and "transversalist" linguistic experimentation, particularly the use of sarcastic and ironic slogans to ridicule all forms of organized politics, including organized autonomia. Mao-Dadism defined itself as a hybrid by-product of both the Chinese Cultural Revolution, when "art [...] became daily life", and the Dadaist rejection of "the separation between art and daily life". ${ }^{21}$ This turn to Dada by "creative autonomia" and its historical link to the surrealist/situationist project need to be reconsidered, in the sense that it was the surrealists, rather than the Dadaists, who rejected the separation between art and daily life. Their consideration of "the surreal" as a revolutionary project led them to communism in the I930s, while the Dadaists tended to remain aloof from organized politics. This surrealist project, which continued with the situationists, then had Dada superimposed back onto it in the late I960s by various European counter-cultural groups. They linked Dada to anarchism and adopted irony, play and theatricality "as political values, and as a new way of making autonomous space. [This] was articulated by these groups [...] by using the language of Dada." ${ }^{22}$ Thus Mao-Dadism was part of a general European counter-cultural reinvention of Dadaism in the I960s and I970s.

The Metropolitan Indians's main contribution to Seventy-Seven was the combination of linguistic experimentation and Situationist

20. Lumley, States of Emergency.

2 I. R. Scordino and DeriveApprodi (eds), '77: L'anno della grande rivolta (Rome, I997, CD), no page numbers.

22. Gavin Grindon, e-mail, I9 December 2006. I thank Gavin for this and other insights on the relation between Dadaism and counter-cultural movements in contemporary European history. 


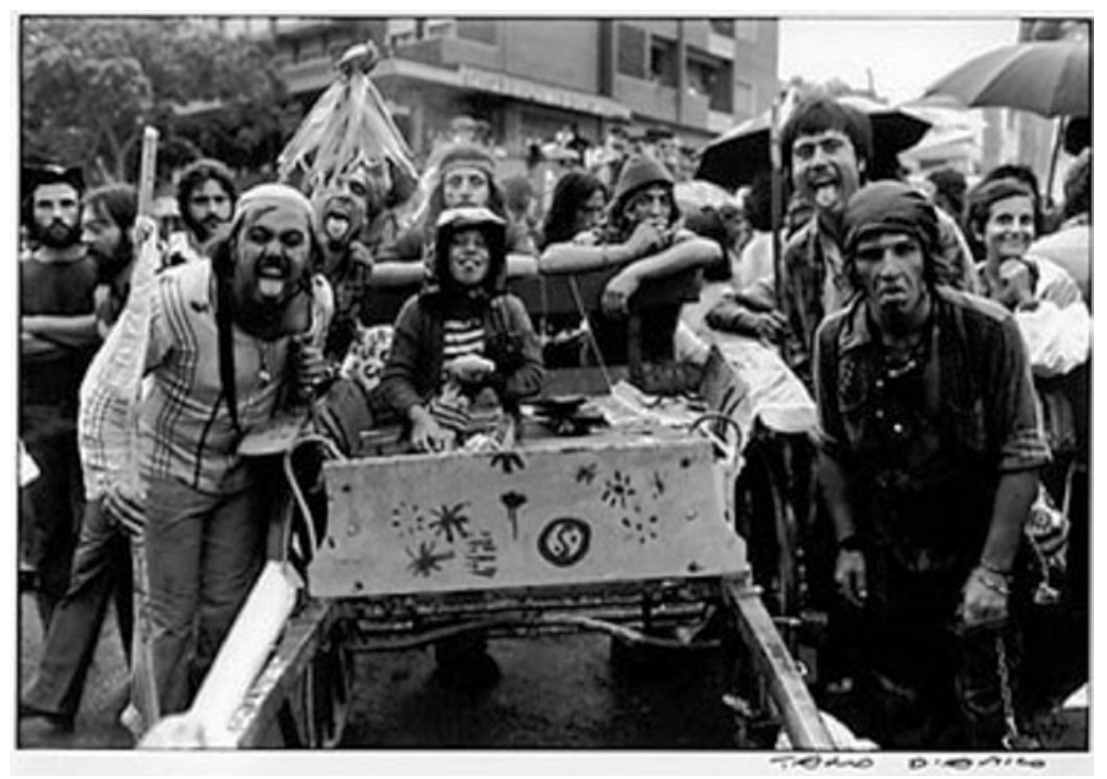

Figure 4. Metropolitan Indians in mockery mode.

Copyright: Tano D'Amico. Used with permission.

detournement ${ }^{23}$ in its leaflets, demonstration slogans, and police-taunting gestures (Figure 3). They used mocking humour and what the semiologist Umberto Eco called "Italo-indian" 24 to attack total institutions and the patriarchal family. As part of the "meeting of the People of Men" they proposed "the immediate practice at the territorial level of militant antifamily patrols to tear away young men and especially young women from patriarchal tyranny". ${ }^{25}$ They made surrealistic demands which

23. "[A] term deriving from the Situationists [which] describes the reassemblage of elements torn out of their original context in order to make a subversive political statement"; Nick DyerWitheford, Cyber-Marx: Cycles and Circuits of Struggle in High Technology Capitalism (Urbana, IL, I999), n. 60, p.I87. The Situationist International was a neo-Marxist movement which emerged from the post-surrealist milieu and was a key influence on the French May I 968 revolts with its analysis of advanced capitalism as a "society of spectacle" based on consumerism and the mass media.

24. "C'é un altra lingua, l'italo-indiano", L'Espresso, I4 (1977); republished in Umberto Eco, Sette anni di desiderio (Milan, 1983), and in Nanni Balestrini and Primo Moroni, L'orda d'oro: 1968-1977. La grande ondata rivoluzionaria e creativa, politica ed esistenziale (Milan, I997. [1988]); trans. Micaela Bogazzi and republ. as "Hay otro idioma, el italo-indiano", in Balestrini and Moroni, La horda de oro (1968-1977). La gran ola revolucionaria y creativa, política y existencial (Madrid, 2006), pp. 6ro-614.

25. Anon., "Gli indiani metropolitani", 3 March 1977 (leaflet); 68-77 gruppi e movimenti si raccontano, http://www.zzz.it/ ago/settesette/volantinill-2Q.htm, (accessed April 200I). 
parodied the political practice of "demanding", asking for the "demolition of the Patriotic Altar, ${ }^{26}$ and its substitution with all forms of vegetation [and] animals [...] and the alternative use of Hercules aircraft as a service to transport young people for free to Machu Pichu (Peru) for the sun party". ${ }^{27}$

However, not all of "creative autonomia" agreed with their somewhat ritualistic use of irony: "The game of reversal is impassioning the Rome movement; once the trick is discovered the game is easy". ${ }^{28}$ Even so, "the trick is old, in France it has a precise linguistic expression - detournement - and it has long been used by the exponents of the historical vanguard [...] precursors could be found among the great English writers of the eighteenth century". ${ }^{29}$ Nevertheless, the power of irony as a linguistic weapon was recognized, as were its limitations:

What interests us is the sense of bitterness that irony leaves us with, its flattening action. Irony opens spaces, it unhinges, it reveals what cannot be hidden anymore [...]. Irony lacks flesh and blood, it is only partially a practice of liberation, as partial as is violence and its organization. $3^{\circ}$

Finally, irony is a frustrating "language that marks the space between our desires and the difficulty of their realization". ${ }^{31}$

The Metropolitan Indians also combined ironic wordplay with theatricality on demonstrations as a self-deprecatory refusal of "serious militancy", deliberately provoking the more earnest militants with their "effrontery of inventing and intoning slogans with a megaphone in the middle of an assembly [...] and hilarious routines such as marching in indian file while intoning the word 'Oask?!' [the name of their zine, an anagram of Kaos]".32 Significantly, these bizarre slogans, were "quickly assimilated by the whole Movement", demonstrating the power of irony as a protest form throughout Seventy-Seven. 33 The "Indians" proved, however, to be more of an ephemeral moment than a lasting tendency, dissolving back into the movement or simply leaving, after the intensification of state repression following the insurrectionary violence of the I 2 March demonstrations in Rome and Bologna. They "did not recognize [themselves] in mass aggregations, [they] liked to invent language-

26. A large marble monument in central Rome, built during fascism, also known derisively as the "typewriter" due to its unusual shape.

27. Anon., "Gli indiani metropolitani".

28. Anon., Zut, 1977; 68-77 gruppi e movimenti si raccontano, http://www.zzz.it/ ago/ autonomia/ironia.htm (accessed April 200I).

29. Ibid.

30. Ibid.

31. Anon., Historias Trastornadas, II, "Indiani Metropolitani", http://www.lisergia.net/interferencias/purgantepublicitario/indiani.html (accessed September 2006).

32. Ibid.

33. Ibid. 
behaviour and to look for another space in which to elaborate [their] poetic of intervention. Already in OASK?! they had signed off as the "Metropolitan Indians in dis/aggregation". ${ }^{34}$

\section{RADIO ALICE AND “TRANSVERSALISM”}

Transversalism, named after Bologna's A/Traverso magazine, was another example of the central role of language in the 1977 Movement. It attempted to undermine language's socially controlling norms through the use of Lewis Carroll's "non-sense" and other forms of "interruption" to create a new kind of communication, more suited to the needs of the SeventySeven generation. It influenced the explosion in the independent production of leaflets, posters, bulletins, newspapers, journals and zines that was Seventy-Seven's most lasting material legacy, along with the chants, slogans, and discussions in endless assemblies in schools, university faculties, and "occupied social centres". Transversalism was theorized within the major social themes but outside the constraints of worn-out ideological categories, such as the "proletariat" and the "middle class". As feminism had already done, it opposed every ideological system. The "everyday" was to be lived as a "revolutionary moment" in all its components, necessitating the constant deployment of inventiveness and creativity. Hence the ironic use of language, the "non-sense", the claims to the right to travel for free (with counterfeited train tickets), the right to free cinema, and the theory of technical-scientific intelligence that led to strangely haphazard traffic lights and free international calls from telephone booths. ${ }^{35}$

The urban youth movement, like the women's movement, had a wide repertoire of resources and skills to mobilize. The mushrooming of "free radio" stations (radio libere) in the main cities in the mid-I 970 s made them the sounding board and cultural laboratory of the movements. Through phone-ins, ordinary people's rich store of experiences addressed the real problems of everyday life that were ignored by the mainstream media. The use of "non-sense", to go through the "looking-glass" of reality, helped to mirror the outside world. However, most radio stations closed down more through lack of skills and funds than police action. There was a failure to articulate and develop autonomous practices, although the present extensive network of free radio stations is thriving, if in a less experimental format. ${ }^{36}$

Radio Alice was founded by former Potere Operaio militants and began broadcasting in 1974 as the first "free radio station". It broke all the norms 
of communication, something never done before by the Italian Left. The writer and academic Enrico Palandri, then a student militant and poet, describes his involvement in the radio:

When I came to Bologna in 1975 very soon I began to work with Radio Alice. At first I did a programme with some friends on poetry late at night. [...] meeting these people who were slightly older than us, who had been in the ' 68 movement and had set up the radio. [...] [During the rioting following the killing of a student in March] there were a lot of phone-ins and we all listened. The police broke in and closed the radio. This was reported live because the people in the radio were very clever. They hid the microphones and left the lines open. After that there were numerous arrests. 37

Seventy-Seven's evident capacity for cultural innovation and experimentation lay in its use of new languages and forms of antagonist communication, the latter defined as the expression of real behaviours, not abstract reflections to be proposed as a separate product from the struggles. The free radio stations, most famously Radio Alice, and to a lesser extent the more "political" Radio Sherwood in Padua and Radio Onda Rossa in Rome, became the sites not just of a localized dissemination of counter-information and subversive ideas, through the cronisti a gettone (telephone kiosk reporters) and phone-ins, but also the locus for continual linguistic experimentation through the use of transversalism, MaoDadaism, non-sense and a mixture of false and real news under the slogan: "Let's spread false news that produce real events". ${ }^{38}$ The most infamous prank was the false edition of La Repubblica (a centre-left national daily newspaper), produced by Il Male, a satirical magazine. Its front page splash featured the improbable "arrest" of Ugo Tognazzi, a popular comic actor, as the grande vecchio (godfather) behind the Red Brigades, so ridiculing the press's obsession with terrorist conspiracy theories.

The magazine A/traverso, linked to Radio Alice, first appeared in Bologna in 1975 as a supplement to Rosso, then the main publication of organized autonomia. However, the growing ideological divisions between "creative" and "organized" autonomia soon led to a parting of the ways. It attempted to be an organ of continuous and open research on the general problems of language, the private sphere, and of intelligence in confrontation with power by going beyond the rigid ideological schemes of political organizations, but also beyond the prevalent debates on the crisis of militancy and the emergence of "secondary needs". ${ }^{39}$ It was born, not by chance, in Bologna, where the model of "actually existing

37. Interview with Enrico Palandri, June 1999 (London).

38. The slogan "Diffundiamo notizie false che producono eventi veri" described a widespread practice among the "free radio" stations.

39. Agnes Heller's La teoria dei bisogni in Marx (Milan, 1974) was an influential text within Seventy-Seven, as were the works of the post-structuralists Foucault, Deleuze, and Guattari. 
socialism" presented by the "Red Junta" of the ICP and ISP proved unattractive to much of that city's youth. The movement revolutionized language with conscious research, retrieving the printing methods of the underground culture. By using newspaper clippings, handwriting, and typewritten white paper, it created a new printing format that allowed flexible imagination to go beyond previous typographic schemes..$^{\circ}$

The intellectual most intrigued by, and as a sociologist at Bologna University, one of the most informed about, the transversalist discourse and praxis was Umberto Eco. He identified a fundamental switch in the semiotic strategies of the new social movements from the moral seriousness of the Marxist-Leninists to the irony of the students and counter-cultural youth. The inherited wisdom of the Old and New Lefts was turned on its head ("More churches, less houses!") and was used to torment the ICP. Eco claimed that the "new generations" were "living a [...] multiplicity of languages of the 'avant guard' in their daily lives". ${ }^{\mathrm{I}}$ The most interesting aspect for him was that "this language of the divided subject, this proliferation of apparently uncoded messages, is understood and practised to perfection by those who until today were extraneous to high culture" ${ }^{42}$ In contrast, the linguistic experts of "high culture" were only able to understand the "language of the divided subject" when it was spoken in a laboratory and could not understand it "when spoken by the masses". ${ }^{43}$ Eco's analysis helps to explain why the irony and experimental language of the "creatives" not only exasperated officialdom and the Old Left, but also caused major rifts within the movement itself between the "creatives" and the "politicos", a fault line that can still be found in contemporary anti-capitalist movements.

\section{CONCLUSION}

Seventy-Seven marked the end of the 1968 historical, cultural and political cycle and the beginning of a new one, which, arguably, continued in Italy during the I980s and I990s, above all through the centri sociali (squatted social centres) movement. The movement's long-term significance has come to be seen as primarily socio-cultural, with its dominant characteristics of counter-cultural and linguistic innovation, particularly in communicational forms. Through the use of irony, detournement, sarcasm, parody, satire, mockery, puns, and anagrams, antagonistic political humour disoriented "the fundamental laws of human language [...] subverting the discipline of their valorization" 44 . However, the intense

40. Scordino and Derive Approdi, '77.

4I. Eco, "Hay otro idioma, el italo-indiano", p. 6 г 2.

42. Ibid.

43. Ibid.

44. Maurizio Torealta, "Painted Politics", in Italy: Autonomia, pp. 102-107, 104. 
political mockery deployed by the Metropolitan Indians, the movement's most visible if relatively short-lived counter-cultural tendency, was not exclusively reserved for the political system and the institutional Left. The more self-importantly "serious" sections of Seventy-Seven, generally those more closely related to the vanguardist traditions of the New Left, were also made the butt of movement in-jokes, so hampering and disarming their attempts to gain "hegemony" over the movement.

The Metropolitan Indians and the transversalists of Radio Alice were not the first to use irony as provocation, Dadaism or linguistic experimentation as political action. Some preceding groups included the Situationist International, the Provos in Amsterdam, Kommune I in Germany, Black Mask in New York, and in Britain King Mob, who, dressed as Santa Claus, went into a department store on Christmas I968 and began handing items from the shelves to children as "presents". These were later confiscated by the police while Santa was arrested.45 These groups used individual actions and stunts to gain publicity for political reasons, while the "creatives" of Seventy-Seven were a mass phenomenon and part of a broader social movement, whose repertoire also included armed violence, but whose overriding characteristic was its desire both to express itself through and play with words in a politically subversive fashion. In this sense the "post-political" I 977 Movement broke with the more "political" movement cycle of the I960s and I970s and presaged the rise of the media-dominated "information society" in the eighties.

Thirty years have passed since the I 977 Movement changed the face of Italian movement politics, before being stigmatized by the media, isolated by the party system and criminalized and repressed by the state. Much of the contemporary global anti-capitalist movement also relies on various forms of humour and play, rather than the ideological browbeating of vanguardism, let alone organized violence, to make their points. The use of intense theatricality, camp mockery, and ironic provocation is now collectively organized as the "pink and silver" block of the alter-globalist movement, whose most notable exponents are the pink fairies of Tactical Frivolity, given to tickling riot police men with their feather dusters. Today's humour is probably gentler than the biting irony of the Metropolitan Indians, capable of provoking the violence of outraged ICP militants or a charge by the riot police, but the message is the same: language is the site of political struggle and the derisory laughter born of irony is one of the most potent weapons a social movement has, humiliating the "powerful" and inspiring the "powerless".

45. Gavin Grindon, e-mail. 